U. S. DEPARTMENT OF AGRICULTURE, BUREAU OF ANIMAL INDUSTRY.-CIRCULAR 146.

A. D. MElvin, Chief of Bureau.

\title{
FISHY FLAVOR IN BUTTER.
}

BY

L. A. ROGERS,

Bacteriologist, Dairy Division.
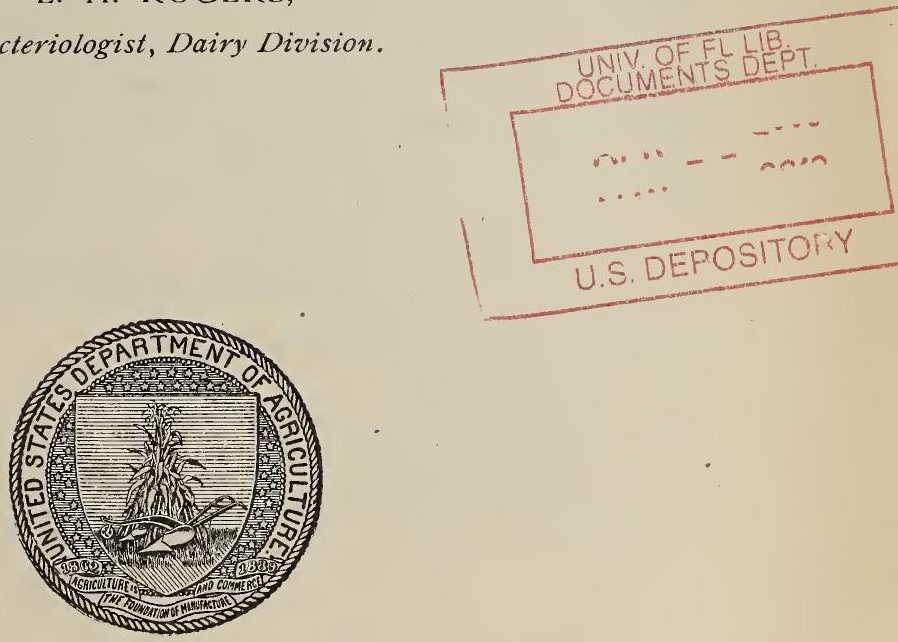

WASHINGTON :

GOVERNMENT PRINTING OFFICE.

1909. 


\section{LETTER OF TRANSMITTAL.}

U. S. Department of Agriculture,

Bureau of Antmal Industry,

Washington, D. C., March 11, 1909.

SIR: I have the honor to transmit herewith, and to recommend for publication as a circular of this Bureau, the manuscript of an article on "Fishy Flavor in Butter," by L. A. Rogers, of the Dairy Division. Fishy flavor is a well-known depreciating factor in the butter trade of this country, particularly in certain sections, and has caused considerable losses. Its cause has been a mystery, and butter experts have been at a loss to account for its appearance. Since 1905 the Dairy Division has been working on the problem, and the investigations reported by Mr. Rogers in the accompanying paper throw considerable light on the subject. It is believed that his conclusions regarding the cause and prevention of the trouble will be of much practical value to butter producers.

Respectfully,

. Hon. James Wilson, Secretary of Agriculture.
A. D. Melvin, Chief of Bureau. 


\section{CONTENTS.}

Introduction

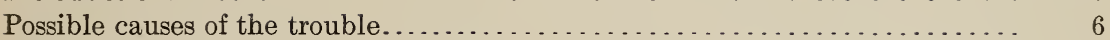

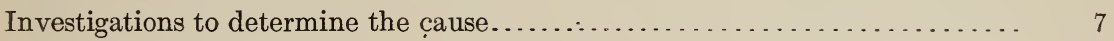

Work with Ö̈dium lactis..................................... 7

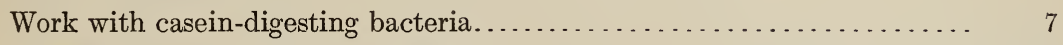

Investigation of conditions on farms......................... 8

Influence of acidity ...................................... 10

Influence of overworking ............................... 12

Conclusions.................................................. 18

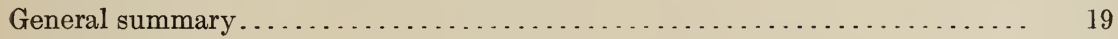

Acknowledgments........................................... 20

\section{IL LUSTRATIONS.}

Fig. 1. Apparatus used to determine relative amount of air in butter by absorp-

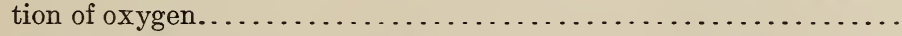

2. Apparatus used to determine relative amount of air in butter by differ-

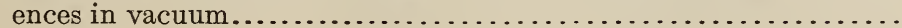

Page.

[Cir. 146]

(3) 


\section{Digitized by the Internet Archive}

in 2016 


\section{FISHY FLAVOR IN BUTTER.}

\section{INTRODUCTION.}

Of the undesirable flavors of butter the various oily flavors may be classed as the most objectionable and troublesome. They range from a slight suggestion of an oil to a strong flavor of machine oil. In the latter case the inferior quality of the butter becomes evident even to the indifferent consumer. Fishy flavor, which is one of the most common of the oily flavors, gives to butter a peculiar oily taste suggesting mackerel or salmon. Butter is frequently described as fishy which is merely oily or otherwise off flavor, but the typical flavor of fishy butter is never mistaken for any other.

Although there are very few references to this subject in literature, the trouble is widely distributed. It is said that it has existed in Denmark, but that it has been almost entirely eliminated by improved methods and care in propagating starters. ${ }^{a}$ It is found in butter exported from Australia to England. It is known to occur in various parts of the United States, but is especially prevalent in the newer dairying sections of the Middle West. In one region this trouble occurs so frequently that it is spoken of among Chicago commission men as the "fishy belt." A large part of the butter made in the central creameries in which the cream is received in a sour or otherwise fermented condition develops fishy flavor if it is held in storage for any length of time.

There are many creameries where fishy flavor appears year after year. These creameries are not necessarily among those making poor butter or receiving overripe, hand-separator cream. On the contrary, a list of them would include many using the most approved machinery and methods and managed by competent butter makers.

Fishy flavor may develop in butter within a week or ten days after making, or it may not appear until the butter has been several months in storage. In the warm summer months butter is frequently fishy when it reaches the commission merchant. Sometimes this condition develops in one shipment alone, or in a few tubs in a shipment, but it is not uncommon for the trouble to persist in a creamery for days or even weeks. Outbreaks of this kind almost always occur during

$a$ Personal conversation with Dr. G. V. Ellbrecht, dairy councillor, Royal Agricultural Society of Denmark.

[Cir. 146] 
or following warm weather. It is generally believed that fishy flavor is most common in hot, rainy seasons.

The most serious loss from fishy flavor is not caused by its appearance in fresh butter but in that held in cold storage. Low temperatures retard, but do not prevent, the development of this flavor. At $32^{\circ} \mathrm{F}$. there is little retarding influence, but at $10^{\circ} \mathrm{F}$. its appearance is perceptibly delayed. At $10^{\circ}$ below zero the retardation is very marked, but even at this extremely low temperature butter may become fishy. Butter held in cold storage for several months without becoming fishy frequently becomes so after leaving storage before it can be sold by the retailer.

\section{POSSIBLE CAUSES OF THE TROUBLE.}

Many theories and hypotheses as to the cause of the trouble have been advanced, but most of them are unsupported by any experimental evidence. The immediate cause is generally ascribed to the presence of trimethylamin in the butter. This is frequently found among the decomposition products of many of the digesting bacteria, and can be produced in butter by the decomposition of casein or albumen.

The opinion has been held by butter dealers that fishy flavor was caused by certain brands of salt, and even now butter makers are sometimes advised to correct this fault by the use of a different salt. But a superficial examination of the conditions under which this trouble appears and of the factors which seem to control it excludes salt from the list of probable causes. It has also been suggested that ice, which in many creameries is added directly to the cream, may be the cause, but as fishy flavor sometimes develops in butter made from cream to which no ice has been added, this may be excluded as well.

It is within the range of possibility that the feed of the cows may have an influence by supplying some unusual constituents to the milk which by their decomposition give the fishy flavor to the butter. It is well known that the feed of cows has a decided influence on the taste of their milk, and while the resulting flavor ordinarily appears at once, this does not necessarily always follow, and the effect may not be evident until the milk has been made into cheese or butter.

It has been suggested that there may be a direct connection between the algæ commonly found in stagnant water and fishy flavor in butter. ${ }^{a}$ This theory is based on the fact that the fishy flavor of drinking water is caused by certain of the algæ, and it is further supported by the great abundance of stagnant water all through the "fishy belt" and the rapid increase of algæ in the warm wet weather which is commonly associated with outbreaks of fishy flavor in butter.

$a$ Piffard, H. G. New York Produce Review, vol. 13, No. 2, p. 20. New York, Nov. 13, 1901.

[Cir. 146] 
O'Callaghan ${ }^{a}$ in New South Wales decided from his observations and investigations that this trouble was caused by the fungus Ö̈dium lactis.

When the present investigation was started the most common and most probable hypothesis was that fishiness in butter was caused by bacteria, either by some particular variety or by some particular decomposition which could be brought about by any one of a number of species of bacteria. Assuming the immediate cause of the flavor to be trimethylamin, we would expect to find it produced by some bacterium or group of bacteria capable of growing in milk and cream in considerable numbers and producing there an enzyme which would decompose the casein of the butter even at the low temperatures of commercial cold storage.

\section{INVESTIGATIONS TO DETERMINE THE CAUSE.}

\section{WORK WITH OÏDIUM LACTIS.}

O'Callaghan, as previously mentioned, asserts that he has demonstrated the immediate connection between this fungus and fishy flavor. In a later paper he states that he can always tell if butter will or will not become fishy by determining the presence or absence of Ö̈dium lactis. $^{b}$ His experiments are not given in detail. The writer, however, has been unable to produce by inoculations with Ö̈dium lactis any flavor resembling fishiness, although three varieties purchased from Kral's laboratory were used in addition to a number isolated from domestic butter. This fungus is not very common in American butter and has never been found in more than very small numbers in samples of fishy butter examined by the writer. Furthermore, many lots of fishy butter have been made in which Ö̈dium lactis was known not to occur either in the butter or in the cream from which the butter was made.

Ö̈dium lactis may be the cause of what is known as "fishy flavor" in Australian butter, and it may even occasionally cause fishy flavor in American butter, but it is certain that it is not the common cause in this country.

\section{WORK WITH CASEIN-DIGESTING BACTERIA.}

During the first season in which the investigation of this trouble was systematically undertaken, bacteriological studies were made as thoroughly as the circumstances would permit of the cream in a number of creameries where there were outbreaks of fishy flavor. It was hoped to find in this way some form of bacteria common to all

a O'Callaghan, M. A. Fishy-flavored butter, the cause and remedy. Agricultural Gazette of New South Wales, vol 12, pt. 3, pp.341-346. Sydney, N.S. W., March, 1901.

$b$ O'Callaghan, M. A. Butter classification: The scientific examination of butter for export to England. Agricultural Gazette of New South Wales, vol. 18, pt. 3, pp. 223-227. Sydney, N. S. W., March, 2, 1907.

[Cir. 146] 
creameries having this trouble which would produce fishiness in controlled inoculation experiments.

In addition to the common lactic-acid type, two or three forms were found in large numbers in all the affected creameries. These were not new or uncommon varieties, but were always present in large numbers and were the only bacteria, excepting the lactic-acid group, sufficiently numerous to account for any unusual condition. One of these was Bacterium lactis aerogenes, which was always present in more than ordinary numbers, especially in the hand-separator cream. A second type was a coccus forming on gelatin small, round colonies surrounded by a clear, saucer-shaped liquefaction. Milk was curdled with an acid reaction and subsequent peptonization. This form was always present, frequently in large numbers, and grew readily in competition with the lactic-acid bacteria until considerable acid was developed. Other liquefiers occurred so irregularly and in such small numbers that they were not considered. One form characterized by its curious filamentous colonies was always found, but in small numbers only. However, inoculation experiments with these bacteria, either singly or in combination, gave only negative results, although they were repeated many times. Trimethylamin was separated in small quantities from milk cultures of the liquefying coccus, but it soon became evident that it had no direct connection with fishy flavor in butter.

It was found that large quantities of trimethylamin could be worked into butter without producing any trace of fishy flavor. Fishy butter was mixed with water made acid with sulphuric acid and distilled, and the distillate had a decided fishy odor and taste. The same flavor was found in the distillate from an alkaline solution. It is therefore evident that the fishy flavor of butter is not caused by anything of a basic or of an acid nature. These results exclude trimethylamin and suggest an aldehyde which could be produced in a great variety of decompositions and by many kinds of bacteria.

\section{INVESTIGATION OF CONDITIONS ON FARMS.}

In the second season's work an attempt was made to find one or more farms producing milk from which fishy butter could be made, so as to compare the conditions with those on farms where the trouble did not appear. In this way many of the complications unavoidable in a creamery could be eliminated, and it was hoped that a comparison of the bacteria, the flora of the pastures, and the general conditions would reveal something common to the fishy-flavor farms which did not exist on those producing normal butter.

A temporary laboratory was established at a creamery in Wisconsin where this trouble had been known to appear every summer for several years. Milk was taken from the patrons' cans at the intake and sepa[Cir. 146] 
rated in a hand separator. The cream was allowed to ripen spontaneously and was churned in glass jars. The butter was packed in small glass jars and stored in the creamery refrigerator. By this method it was determined that the milk from certain farms made typical fishy butter on both the first and the second trial, while other farms were found producing milk which made butter with no abnormal flavor.

A thorough botanical survey of these farms was made by Mr. L. S. Cheney, whose long experience with the Wisconsin State geological and biological survey especially qualified him for this work. On account of its negative nature his report is not given. He found that no condition existed in the pastures and on the farms furnishing milk from which fishy butter was made which did not exist on some of the farms producing normal butter. This applied to the water supply as well as to the flora of the pastures. These results seem to exclude the possibility of any direct connection between the feed of the cows and the presence of the fishy flavor in the butter. We have, however, been unable by any combination of circumstances to produce fishiness in butter made under winter conditions. It is not unlikely that slight differences in the composition of the butter due to variations in the feed may account for this fact. This variation is evidently a general one and is not peculiar to localities where fishy flavor exists.

Bacteriological examinations of the mixed cream as it came from the separators at the creamery were made throughout the summer, and it was found that in a general way the variation in the bacterial flora of the cream was slight and was quantitative rather than qualitative. Although this creamery received no complaints of fishy flavor that season, fishy butter was made experimentally from the mixed cream, which was allowed to ripen spontaneously. The records of the bacteriological examinations showed no noticeable variation from the normal bacterial content at the time this butter was made.

Bacteriological examinations were made from the milk of farms producing milk from which fishy butter could be made, and the bacterial floras revealed by these examinations were compared with the bacterial flora of farms that furnished milk from which normal butter was made. It was evident from this work that there were no unusual varieties of bacteria connected with the production of the off flavor.

The possibility that this flavor might be produced by the development of bacteria not shown by ordinary culture methods is excluded by the results of an experiment made by Mr. C. E. Gray. In this work a starter was added to a lot of cream which had spontaneously overripened, and it was then pasteurized at $180^{\circ} \mathrm{F}$. It is well established that practically all vegetable bacteria are killed at this temperature. The cream was cooled and churned at once, thus eliminating the possibility of any material development of bacteria after pasteurization. Before going into storage the butter was examined 78589-Cir. 146-09-2 
and classed as fair butter, with no trace of fishy flavor. After four months in storage at $-10^{\circ}, 10^{\circ}$, and $32^{\circ} \mathrm{F}$, it developed a very strong fishy flavor. Bacteriological checks were not made on this butter, but the growth of bacteria in butter stored from $20^{\circ}$ to $40^{\circ}$ below the freezing point is impossible, and the development of bacterial enzymes in the cream after pasteurization is highly improbable.

A more detailed study of the lactic-acid bacteria showed the presence of unusually active bacteria of this group in the milk from the fishy-flavor farms. Inoculation experiments were made, using bacteria isolated from the cream which made fishy-flavored butter. Cultures were used both singly and in various combinations. Butter made in this way frequently developed fishy flavor, but the results did not consistently connect that flavor with any particular variety or combinations of bacteria.

\section{INFLUENCE OF ACIDITY.}

An analysis of the records of all the inoculated butter which developed fishy flavor shows that this flavor always occurred in butter made with an active lactic-acid organism or in which a high degree of acidity had been developed with ordinary lactic-acid bacteria. Results obtained from butter made in other investigations and reported elsewhere ${ }^{a}$ throw light on this observation.

In Table 1 are given the results of butter made from one lot of cream to show the influence of varied degrees of acidity on the keeping quality of the butter.

TABLE 1.-Results of experiments showing influence of varied degrees of acidity on the keeping quality of butter.

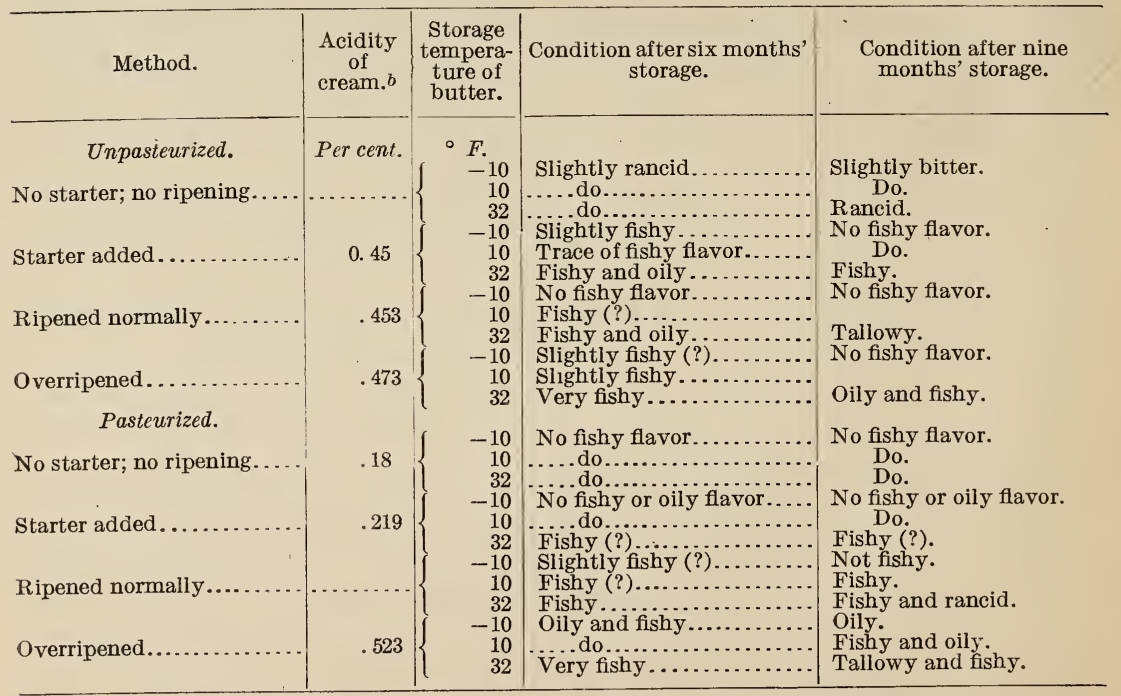


This table shows that the development of fishiness was clearly associated with the development of acidity in the cream. The fishy flavor was much more pronounced in the higher acid butters, especially in those stored at the higher temperatures. In the pasteurized cream butter, in which the acid was better controlled, the relation is evident. In the sweet-cream butter there was no trace of oily or fishy flavors. In the butter made with starter but without development of acid there was no trace of these flavors when stored at the lower temperatures, and only a doubtful appearance at $32^{\circ} \mathrm{F}$. was found after nine months. In the ripened pasteurized butter there was a questionable fishiness in the butter stored at the lower temperatures and a distinct fishy flavor at $32^{\circ} \mathrm{F}$. After nine months the fishy flavor had developed in the butter held at $10^{\circ} \mathrm{F}$. The butter made from overripened cream showed a very pronounced fishy flavor after six months in storage regardless of the storage temperature.

A careful bacteriological examination had been made of the cream at various stages of the ripening, and of the butter before going into storage and at the end of six and nine months periods. At no time was there any development of bacteria other than of the lactic-acid group which could explain this change. Similar results have been obtained many times under varying conditions.

In all the experimental butter made in the last three years there has been no trace of fishy flavor in that made from pasteurized sweet cream churned without the addition of a starter. In butter made from pasteurized cream with starter added but without any subsequent ripening there has been no fishy flavor, with the possible exception of one or two doubtful cases. On the other hand, many lots of experimental butter made from well-ripened cream have developed a marked fishiness.

The relation of the acid to the fishy flavor has been demonstrated in butter made from pasteurized cream in which considerable acidity was developed by the addition of chemically pure acid. Table 2 shows the results obtained with two lots of butter made from pasteurized cream in which varying degrees of acidity were produced by the addition of pure acids. Bacteriological examinations of these creams showed only an insignificant development of bacteria. The butter was packed in sealed cans and stored for six months at $10^{\circ} \mathrm{F}$., when it was examined by Mr. P. H. Kieffer. His comments show that a certain amount of acid is essential to the production of fishy flavor and that acids other than lactic will give this result.

[Cir. 146] 
TABLE 2.-Fishy flavor in butter made from artificially acidified cream.

\begin{tabular}{|c|c|c|c|c|c|}
\hline \multirow{2}{*}{ No. } & \multirow{2}{*}{ Cream acidified with- } & \multirow{2}{*}{ Acid. } & \multicolumn{2}{|c|}{ Score. } & \multirow{2}{*}{ Comments. } \\
\hline & & & Flavor. & Total. & \\
\hline A $\begin{array}{l}1 \\
2 \\
3 \\
3 \\
1 \\
2 \\
3\end{array}$ & 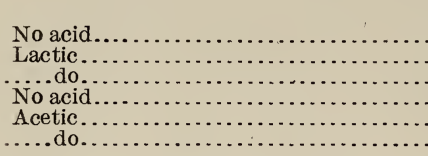 & $\begin{array}{r}\text { Per cent. } \\
0.144 \\
.216 \\
.432 \\
.126 \\
.216 \\
.350\end{array}$ & $\begin{array}{l}38 \\
38 \\
35 \\
38 \\
35 \\
28\end{array}$ & $\begin{array}{l}93 \\
93 \\
90 \\
93 \\
90 \\
83\end{array}$ & $\begin{array}{l}\text { Fishy. } \\
\text { Do. }\end{array}$ \\
\hline
\end{tabular}

It is evident, therefore, that there is a direct relation between the acidity of the cream and the development of fishy flavor in the butter. However, as the work progressed it became apparent that acidity, although having a determining influence on fishy flavor, was not its sole cause. With this factor controlled it was impossible to make butter with any certainty that it would become fishy. Frequently butter made from cream with a high acidity showed no trace of this flavor.

\section{INFLUENCE OF OVERWORKING.}

It has been said by butter dealers that fishy flavor is caused by a poor "body," or at least that the two are always associated. The statement has also been made to the writer that fishy flavor could be produced by overworking the butter. ${ }^{a}$ This opinion has been confirmed by results obtained in the course of this investigation. The following case is an illustration: Three tubs of butter made from one lot of cream were divided after five months in storage at $10^{\circ} \mathrm{F}$., and one-half of each tub was badly overworked on a hand worker. Eighteen days later the butter was examined by a competent butter judge who knew nothing in regard to its treatment. His comments are given in the following table:

TABLE 3.-Influence of overworking on storage butter.

\begin{tabular}{|c|c|c|c|}
\hline No. & Acidity. & Working. & Comments. \\
\hline $\begin{array}{l}1 \\
2 \\
3\end{array}$ & 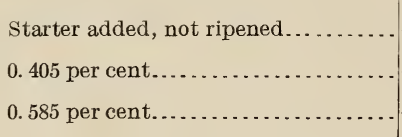 & 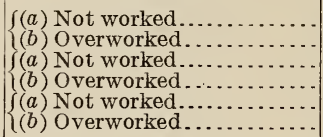 & $\begin{array}{l}\text { Age. } \\
\text { Oily, trifle rancid. } \\
\text { Suggestion of fishy; fruity. } \\
\text { Fishy. } \\
\text { Age and acid. } \\
\text { Badly fishy and age. }\end{array}$ \\
\hline
\end{tabular}

It will be noted that fishiness was observed only in a combination of high acid and overworking. This was also found to be true in butter made under more carefully controlled conditions.

In one experiment, to a lot of 33-per-cent cream pasteurized at $170^{\circ} \mathrm{F}$. was added a starter in the form of a milk powder. The use of the powder made it possible to add a starter without increasing the initial acidity of the cream. After adding the starter the cream was divided, and portion 1 was cooled and churned. Portion 2 was allowed to ripen until the following morning. Portion 1 was churned at $48^{\circ} \mathrm{F}$. and portion 2 at $49^{\circ} \mathrm{F}$. The temperature of the buttermilk 
in each case was $55^{\circ} \mathrm{F}$. After 20 revolutions with the rollers in gear, part of the butter was taken out and packed; the butter remaining was worked 20 more revolutions when another part was taken out; the remainder was worked an additional 40 revolutions. The butter (designated as Lot A) was examined when received in New York, eighteen days later, by Mr. Kieffer, who knew nothing of its history. Lot B was treated in a similar way but was made at a different time. The treatment of these butters and the comments of the scorer are given in the following table:

TABLE 4.-Influence of overworking on flavor of butter.

Lot.
$\ldots$

In this butter also is found the same combination of high acid, overworking, and fishiness. The small churns used in these investigations rendered it necessary to churn at a low temperature and to work about 30 revolutions to make butter which would not show mottles. The butter worked 40 revolutions was therefore at most only slightly overworked. No comments were made by the scorers on the body of the butter worked 80 revolutions. This butter was packed in sealed cans bearing serial numbers only and stored at $10^{\circ} \mathrm{F}$. After three months in storage one can from each lot was sent to each of three persons to score. Their comments and scores are given in Table 5:

TABLE 5.-Scores of butter in Table 4 after three months' storage at $10^{\circ} \mathrm{F}$.

\begin{tabular}{|c|c|c|c|c|c|c|c|c|c|c|}
\hline \multirow[b]{2}{*}{ Lot } & \multirow[b]{2}{*}{ Acidity. } & \multirow{2}{*}{$\begin{array}{c}\text { Revolu- } \\
\text { tions } \\
\text { worked. }\end{array}$} & \multicolumn{3}{|c|}{ Score by F. R. B. Co. } & \multicolumn{3}{|c|}{ Score by P. II. K. } & \multicolumn{2}{|c|}{ Score by H. J. C. } \\
\hline & & & Fla- & Total. & ('omments. & Fla- & Total. & Comments. & Total. & Comments. \\
\hline & P. ct. & 20 & 35 & 90 & Old, unclean.. & 37 & 92 & & 88 & Unclean \\
\hline 11 & 0.198 & 40 & 36 & 91 & ..... do. & 37 & 92 & & 90 & olly. \\
\hline & & $\begin{array}{l}80 \\
20\end{array}$ & $\begin{array}{l}39 \\
30\end{array}$ & 94 & Flat.... & 38 & 93 & Very fishy & 89 & Do. \\
\hline 12 & .639 & 40 & 30 & 85 & Very fishy.... & 27 & 82 & ....do..... & 86 & Do. \\
\hline & & $\begin{array}{l}80 \\
20\end{array}$ & $\begin{array}{l}30 \\
39\end{array}$ & $\begin{array}{l}85 \\
93 \frac{1}{2}\end{array}$ & Fiat, trifie & $\begin{array}{l}27 \\
38\end{array}$ & $\begin{array}{l}82 \\
93\end{array}$ & ..... do.... & $\begin{array}{l}85 \\
91\end{array}$ & $\begin{array}{l}\text { Do. } \\
\text { Very oily. }\end{array}$ \\
\hline B 1 & .252 & $\begin{array}{l}40 \\
80\end{array}$ & $\begin{array}{l}39 \frac{1}{2} \\
39\end{array}$ & $\begin{array}{l}94 \\
94\end{array}$ & 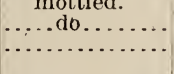 & $\begin{array}{l}38 \\
39\end{array}$ & $\begin{array}{l}93 \\
94\end{array}$ & & $\begin{array}{l}91 \\
91\end{array}$ & $\begin{array}{l}\text { Do } \\
\text { Very oily, trifle } \\
\text { unclean. }\end{array}$ \\
\hline & & $\begin{array}{l}20 \\
40\end{array}$ & $\begin{array}{l}30 \\
31\end{array}$ & $\begin{array}{l}84 \\
85_{2}^{\frac{1}{2}}\end{array}$ & 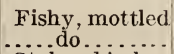 & $\begin{array}{l}28 \\
32\end{array}$ & $\begin{array}{l}83 \\
87\end{array}$ & Slighly fishy. & $\begin{array}{l}85 \\
86\end{array}$ & $\begin{array}{l}\text { Fishy. } \\
\text { Fishy and oily. }\end{array}$ \\
\hline B 2 & .694 & 80 & 32 & 87 & $\begin{array}{l}\text { Stale d is h- } \\
\text { water a } \mathrm{n} \mathrm{d} \\
\text { fishy. }\end{array}$ & 30 & 85 & Fishy..... & 85 & Fishy. \\
\hline
\end{tabular}

[Cir. 146] 
No trace of fishiness appeared in the low-acid butter, while all of the high-acid butter was more or less fishy. Overworking improved rather than impaired the flavor of the unripened cream butter, but evidently hastened the appearance of fishy flavor in the ripened cream butter. This deduction may meet with objection on the ground that the working produces only a physical change which can not affect chemical changes taking place weeks and even months later. However, consideration of well-known facts shows that the working is more complex than appears at first thought, and that by this process new factors may be introduced which can influence the subsequent changes. It is well established that when butter is worked in contact with water, especially at comparatively high temperatures, the water is thoroughly incorporated into the butter. If this process is properly controlled the incorporation is so complete that the water is not perceptible to the eye. Similarly, air is worked into butter in the ordinary process of working, and the whitening effect of overworking, which is easily demonstrated, is due to the air thus introduced. It is probable that this is not a bleaching but the physical effect of innumerable minute air bubbles. The whitening of a dark candy under the manipulation of a candy maker is a familiar example of this same effect. The fact that butter made by the usual methods contains air may be shown by putting a piece of butter in a jar of cold water and exhausting the air. Five or 6 cubic centimeters of air may be obtained in this way from 100 grams of butter. The exact amount of air contained in the butter could not be readily determined owing to the difficulty of separating the bubbles from the entangling mass of curd.

That the amount of air in butter is increased by overworking was demonstrated by adaptation of an apparatus used by Barcroft ${ }^{a}$ to determine the relative amount of oxygen in venous and arterial blood. The apparatus as used in this work consisted, as shown in figure 1, of a U-tube $(a a)$ fastened on a support with a scale. The U-tube is filled to $c c$ with mercury. The remainder of the tube is filled with water. Connected with each arm of the U-tube by rubber tubing are bottles $(b b)$ of equal capacity, with rubber stoppers through which is passed glass tubing. The butter to be compared is weighed into the bottles. It is necessary to warm the butter to a semifluid condition in order to avoid the errors due to air held in mechanical holes. The flasks are then filled completely with an alkaline solution of pyrogallic acid at $40^{\circ} \mathrm{C}$. and the stopper put in place with precautions to avoid the retention of air bubbles. The stoppers are pressed in until the rubber tubes are filled and then wired securely in place. The tubes are then connected with the U-tube and so adjusted that the two columns of

$a$ Barcroft, Joseph. Differential method of blood-gas analysis. Journal of Physiology, vol. 37, No. 1, pp. 12-24. London, May 6, 1908.

[Cir. 146] 
mercury are at the same level. The bottles are immersed in a water bath at $40^{\circ} \mathrm{C}$. and shaken gently until the fat is thoroughly melted and all the oxygen and carbon dioxid absorbed. If the sample in one bottle contains more air than the other the reduction in pressure due

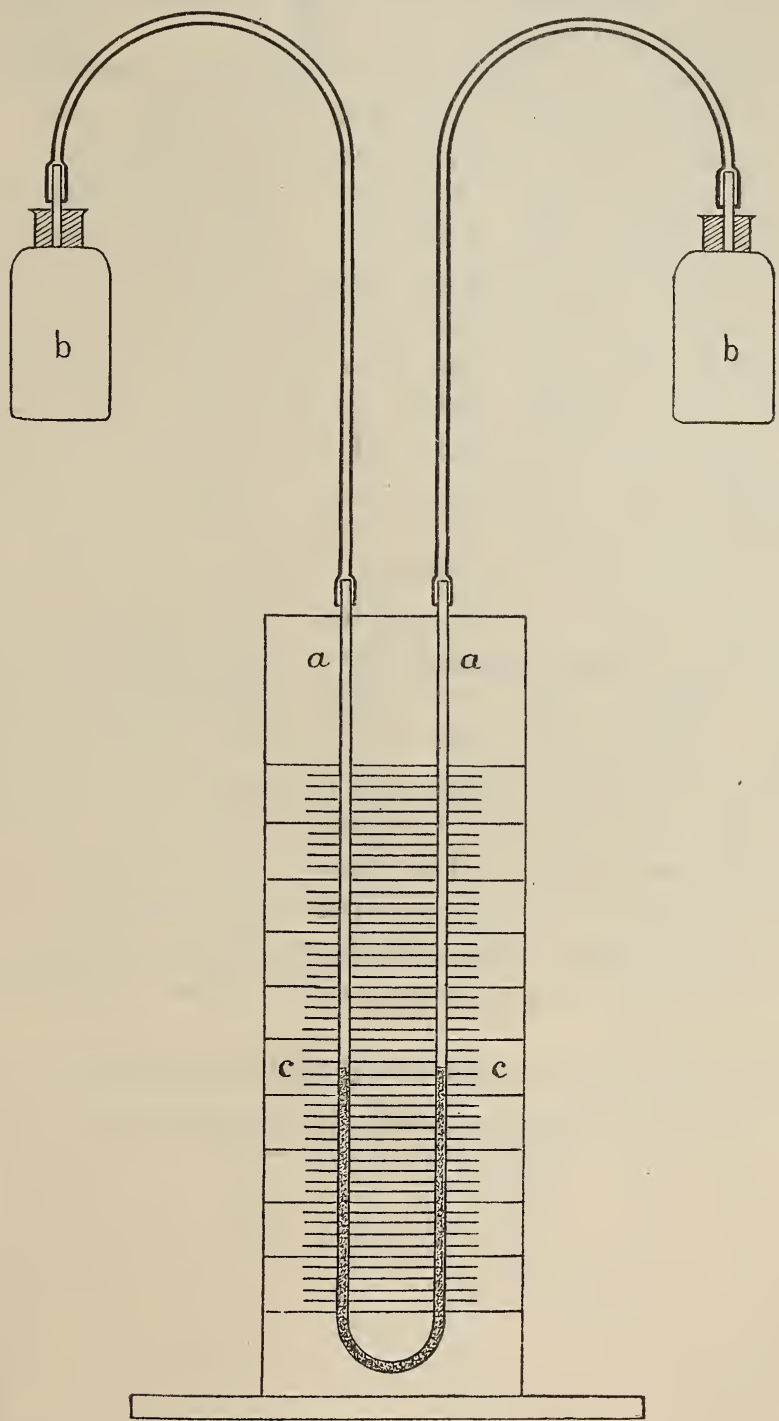

FIG. 1.-A pparatus used to determine relative amount of air in butter by absorption of oxygen.

to absorption of gases will be greater and the mercury will rise in the arm of the U-tube with which this flask is connected.

Butter badly overworked with a spatula always shows a distinctly higher oxygen content than an unworked portion of the same sample [Cir. 146] 
when they are compared by this method. The difference is usually equivalent to about 0.2 cubic centimeter of gas absorbable by alkaline pyrogallic acid solution for every 10 grams of butter when measured under these conditions. This indicates an increased air content of over 10 per cent. With butter overworked in a churn the difference is small but distinct.

Similar results were obtained with an apparatus arranged as shown in figure 2. This consisted of a salt-mouthed, glass-stoppered bottle of 75 c. c. capacity, into which was sealed a tube of $6 \mathrm{~mm}$. internal diameter and 1 meter long. This tube connected through the stopcock $f$ and a U-bend with a bottle, $c$. The entire apparatus was securely clamped to rods and so arranged that it could be inclined for filling. It was tested to guard against leaks. In operating, the tube $b$ was filled with mercury to the stopcock $f$, the stopcocks $e$ and $f$ were closed, and a definite weight of mercury was poured into the bottle $a$. The mercury filled the tube $b b$ and about two-thirds of $a$. A tube holding about 20 grams of butter was filled with the butter to be tested and the sample forced by means of a plunger out of the tube into the bottle $a$. The stopper was then clamped in place and the stopcock $f$ opened. The mercury flowed through the U-tube into the bottle $c$, where a constant level was maintained by the overflow tube $d$. The vacuum thus produced could be relieved by the stopcock $e$. Comparative tests were made consecutively and in a room in which the temperature was constant within narrow limits; the error due to variation in barometric pressure and temperature could therefore be ignored. The volume of the sample, the volume of air remaining in the bottle $a$, and the vapor tension were constants. The only varying factor, then, which could be expected to influence the height of the mercury column would be the air contained in the butter.

The results with butter overworked with a spatula are as follows:

TABLE 6.-Results of tests showing amount of air in normal and overworked butter.

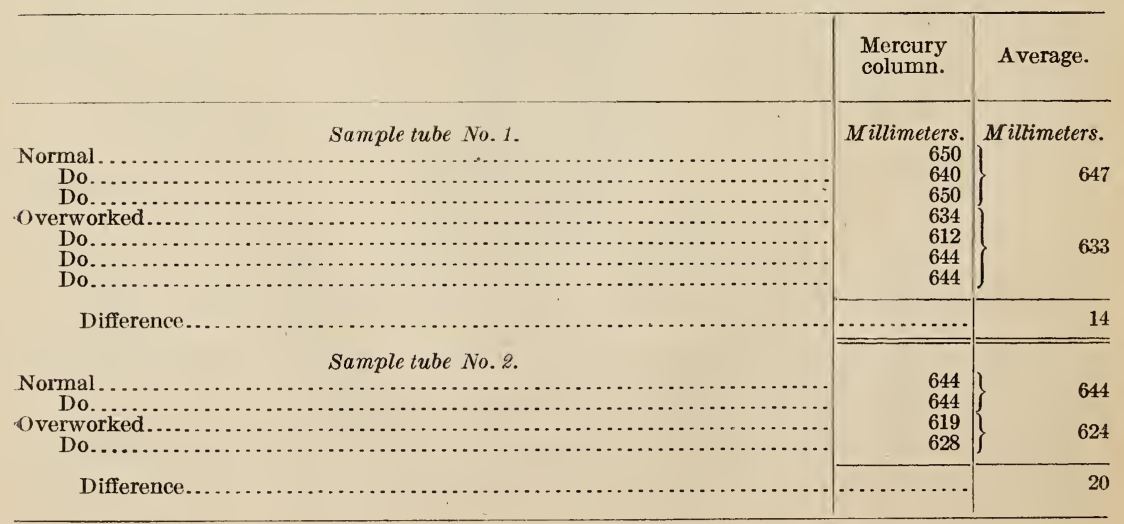

[Cir. 146] 
This method indicated that the overworked butter contained more air than the unworked portion of the same butter, although the normal

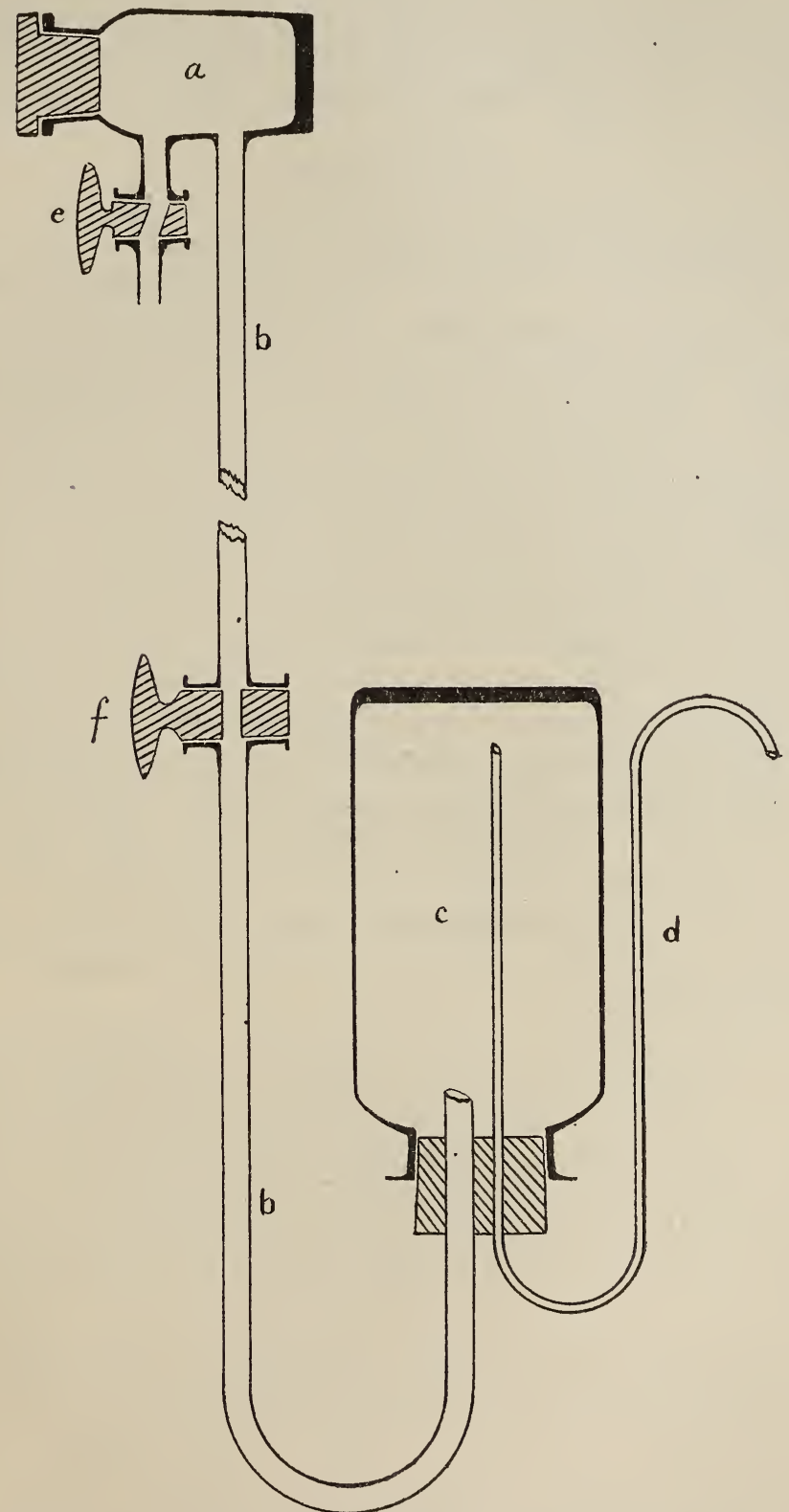

FIG. 2.- Apparatus used to determine relative amount of air in butter by differences in vacuum.

butter contained numerous mechanical openings which were removed by the working. The overworked portion was homogeneous without [Cir. 146] 
visible cracks or bubbles. Overworking not only increases the actual amount of air in butter, but obviously decreases the size of the bubbles and thus increases the area of butter exposed to the action of the air. If the amount of air in a given sample of butter remains constant and the diameter of the bubbles is reduced one-half, the surface area of the bubbles will be doubled and the rate of oxidation correspondingly increased.

\section{CONCLUSIONS.}

Fishy flavor in butter is evidently not produced by the action of any one special factor. The results given in this paper indicate that its immediate cause is a particular substance produced by the oxidation of one of the combinations of the acid developed in the ripening of the cream. The substance oxidized may be the result of a hydrolysis of one of the constituents of the butter by the acid. In the ordinary ripening sufficient acid is produced to make the development of fishy flavor possible. If the cream is overripe and a corresponding high acidity is present the appearance of this flavor is much more probable. Air is probably always present in quantities sufficient to produce fishiness, other factors being favorable, but the development of this flavor is hastened and made more certain by overworking, which increases the air and the oxidizing surface. It is true that in many cases fishiness is not observed in butter made from high-acid cream. This may be because the particular acid combination is not present or because the fishiness is masked by other objectionable flavors usually found in high-acid butter. It is probable also that in the course of the decomposition of the. butter the substance producing the fishy flavor is further oxidized or otherwise changed so that the fishiness disappears.

Fishy flavor, however, is not infrequently reported in butter in which its occurrence could not be explained on this basis. Different scorers have different conceptions of what is included under this term, and many lots of butter are scored fishy which could not be called fishy as the term is used in this paper. This varied use of the term has resulted in some confusion in this and in other investigations, and it has been necessary to exclude results in which there was a difference of opinion and to depend largely on those scorers whom experience has shown to be most consistent and conservative in their judgment.

The deductions drawn from these investigations are in accord with all the facts which are known in regard to this trouble. In newer dairy sections where fishy flavor is common, barns and milk houses are less likely to be well constructed, and there is more probability that the milk comes to the creamery heavily inoculated with acidforming bacteria. This is especially true of the central creameries, where the cream is usually received in a very acid condition. It is 
also true that in hot weather, when fishy flavor is most common, cream is more likely to become overripe and to be churned at a high temperature and consequently overworked.

In Denmark the trouble is less prevalent than formerly, and this has probably been brought about, not by greater care in the selection of starters, but by making a mild-flavored butter from pasteurized cream ripened to a low degree of acidity. The presence of Ö̈dium lactis in Australian butter may be considered, not as the cause of fishiness, but merely as an indication that the butter was made from high-acid cream, a condition which is well known especially to favor the growth of this organism.

The practical application of the work herein outlined is evident. The butter maker who receives whole milk or fresh sweet cream can prevent the appearance of this trouble with certainty. High-grade butter with a low acidity may be made by adding a good starter to pasteurized cream and churning without ripening, or the pasteurized cream may be churned sweet without the addition of any starter. In creameries receiving hand-separator cream in which the acid is well developed the problem is more difficult, and under such conditions it may be impossible to control this trouble. The amount of working the butter receives is almost entirely under the control of the butter maker. The working necessary depends on various factors, but in any case overworking should be avoided. In this the butter maker may have to choose between a low moisture content and the possible depreciation in price on account of fishy flavor.

\section{GENERAL SUMMARY.}

Flavor.-Fishy butter has the peculiar oily flavor of mackerel or salmon.

Geographical distribution.-The trouble is of widespread occurrence, but is most noticeable in newer dairy sections.

Seasonal appearance.-Fishy flavor rarely or never appears in butter made in the cold months and is most likely to appear in fresh butter during a period of hot weather. The trouble may be noticeable in one shipment only, or it may continue to be observed for days and even weeks.

Appearance in storage butter.-It may occur in butter a few days after making, but usually does not appear until the butter has been held in storage. Low temperatures retard but do not prevent the development of fishy flavor.

Ö̈dium lactis. - Contrary to the results reported by O'Callaghan, fishy flavor could not be produced by inoculation with Ö̈dium lactis.

Bacteria.-No species or group of bacteria could be found peculiar to creameries having trouble with fishy flavor. Inoculation experi[Cir. 146] 
ments with bacteria occurring in these creameries failed to connect the trouble with any one kind, and daily bacteriological examinations of the mixed cream in a large creamery failed to show any noticeable variation in the bacterial flora at times when fishy butter was made.

Fishy-flavor farms.-By making butter in small lots from many farms it was possible to find farms producing milk from which fishy butter could be made by allowing the cream to ripen spontaneously. Botanical surveys of these farms showed nothing which could differentiate them from other farms producing butter which did not develop fishy flavor. Bacteriologically, the only peculiarity of the cream from these farms was the presence of very active lactic-acid bacteria.

High-acid cream.-In all cases in which the records were complete it was found that those experimental butters which became fishy were made from high-acid cream. Fishy butter was made from cream acidified with lactic and acetic acids. However, cream with high acidity does not uniformly develop fishiness.

Overworking.-Fishy flavor may be produced with reasonable certainty by overworking the butter made from sour cream.

Cause.-In the opinion of the writer, fishy flavor is caused by a slow, spontaneous, chemical change to which acid is essential and which is favored by the presence of small amounts of oxygen.

Prevention.-Fishy flavor may be prevented with certainty by making butter from pasteurized sweet cream. Butter made from pasteurized sweet cream with a starter but without ripening seldom if ever becomes fishy.

\section{ACKNOWLEDGMENTS.}

The writer wishes to express his appreciation of the assistance rendered by many creamery managers, butter makers, and butter dealers, whose cooperation has made this investigation possible. $\mathrm{He}$ is also under obligations to his former colleague, Mr. C. E. Gray, and many others, for assistance and valuable suggestions.

[Cir. 146] 